\title{
A Potential Bio-sorbent for Heavy Metals in the Remediation of Waste Water
}

\author{
Mohammad A. Laskar ${ }^{* 1}$, Syed K. Ali ${ }^{2}$, Sana Siddiqui ${ }^{3}$ \\ ${ }^{1}$ Department of Chemistry, Faculty of Science, Jazan University, P.O. Box 2079, Jazan, Saudi Arabia \\ e-mail: mdasaduddinlaskar@gmail.com \\ ${ }^{2}$ Department of Chemistry, Faculty of Science, Jazan University, P.O. Box 2079, Jazan, Saudi Arabia \\ e-mail: skali_169@yahoo.com \\ ${ }^{3}$ Department of Chemistry, Faculty of Science and Arts, Jazan University, P.O. Box 797, Samtah, \\ Saudi Arabia \\ e-mail: sana.siddiqui1@gmail.com
}

Cite as: Laskar, M. A., Ali, S. K., Siddiqui, S., A Potential Bio-sorbent for Heavy Metals in the Remediation of Waste Water, J. sustain. dev. energy water environ. syst., 4(4), pp 320-332, 2016, DOI: http://dx.doi.org/10.13044/j.sdewes.2016.04.0025

\begin{abstract}
Bay leaves are used for flavoring in cold drinks production, in bakery goods, sauces, confectionary products and liquors. The waste generated from these sources has been valorized by attempting the remediation of waste water. Hence, adsorption of toxic metals onto Bay leaves has been investigated after optimizing the experimental parameters, namely the $\mathrm{pH}$, contact time, adsorbent and $\mathrm{Zn}$ (II) concentrations as well as the temperature of the equilibrium mixture (consisting of the metal solution in contact with the adsorbent). The participation of the constituent functional groups, of the adsorbent, was ascertained with Fourier transform spectroscopic studies. The mode of adsorption was examined by employing important isotherm models, namely Langmuir, Freundlich and Dubinin-Radushkevich models. The adsorption process was found to follow pseudo-first order kinetic model and also followed the intraparticle diffusion up to 60 minutes of contact time. The thermodynamic parameters suggest the spontaneous nature of adsorption.
\end{abstract}

\section{KEYWORDS}

Green technology, Zinc, Langmuir plot, Freundlich plot, Bio-sorbent, Heavy metals.

\section{INTRODUCTION}

The growing industrialization, coupled with population expansion, has resulted in the excessive release of heavy metals, whereby contaminating the natural resources (or ecosystem) [1,2]. The major sources of metal pollutant are household hazardous wastes, industrial effluents and runoff from agricultural fields [2]. Metals are categorized as Persistent, Bioaccumulative and Toxic (PBT) chemicals and are not easily metabolized [3]. The bioaccumulation of these metal pollutants in human bodies and/or other living beings occurs through exposure over a considerable time either by direct intake or through food chains [2, 4]. As for instance, the bioaccumulation of zinc causes nausea, anemia, skin irritations, vomiting and stomach cramps [5]. Hence, their removal from our natural resources has become a major concern [6].

Till date, various techniques [7] namely coagulation, filtration, ion exchange, solvent extraction, foam flotation, activated sludge, aerobic and anaerobic treatment [8], microbial reduction, electrolysis and adsorption [9], have been employed for the

* Corresponding author 
treatment of metal contaminant. Among these water treatment technologies, adsorption has gained preference over others because of its convenience, simplicity of design and ease of operation. Agricultural by-products/products can be used as potential adsorbents of metal pollutants by virtue of their basic constituents, namely hemicelluloses, proteins, simple sugars, starch, lipids, lignin and hydrocarbons [9]. Moreover, these are economical and eco-friendly, available in abundance, of renewable nature and of low cost [9]. Hence, various agricultural products, namely:

- Rice straw [10];

- Carrot residue [11];

- Chestnut shells [12];

- Coffee husks [13];

- Banana and orange peels [14];

have been successfully applied for the removal of metal pollutants. However, some of these suffer from low adsorption capacity and poor regenerability.

Adsorption of metals onto biomass (like agricultural products or byproducts) involves diverse and complex mechanisms. The species and the origin of the biomass are the major factors which dictate the qualitative and the quantitative mechanisms for adsorption [15]. Hence, attempts are being made continuously to discover low-cost adsorbent with appreciably high adsorption capacity, efficiency and better regenerability.

Likewise, bay leaves (with the binomial name of Cinnamomum tamala) possesses a variety of functional groups, mostly originating from the constituent compounds, namely:

- Linalool;

- Eugenol;

- Cinnamaldehyde;

- $\alpha$;

- $\beta$-pinene;

- p-cymene;

- Camphene;

- $\beta$-phellandrene, etc. [16].

It is an evergreen tropical tree of the Lauraceae family and grows abundantly in the Indian subcontinent, Indo-China region, Bangladesh, Nepal, Bhutan and the Himalayas (upto altitude of 900-2,500 m) [17, 18].

Used bay leaves are a major waste of food and pharmaceutical industries. These are used in cold drinks companies for flavoring, bakery goods, sauces, confectionary products and liquors $[19,20]$.

In this proposed method, an investigation into the potential of bay leaves as a low-cost bio-sorbent, for the removal of zinc(II) ions from aqueous medium, has been made. The adsorption kinetics and equilibrium isotherms have been studied for better insight into the adsorption behavior, thereby making the adsorption mechanism more intelligible for evaluating and interpreting the thermodynamic parameters. The experimental parameters namely amount of adsorbent, concentration of metal ion, temperature and $\mathrm{pH}$ have been optimized for efficient removal of the metal ion.

\section{MATERIAL AND METHODS}

\section{Instruments and equipments}

Flame atomic absorption spectrometry (Agilent, USA) was used for determining the concentration of $\mathrm{Zn}(\mathrm{II})$. A pH meter (Bellstone, India) was employed to measure the $\mathrm{pH}$. A mechanical shaker of $200 \mathrm{rpm}$ (Bellstone, India) was used for the equilibrium studies. 
The FT-IR analysis (Omnic, USA) was done for characterization. Heating oven (Bellstone, India) was used for drying. A stainless steel grinder was used to reduce the adsorbent to powder. ASTM standard sieves were used to separate particles of the desired size.

\section{Preparation of reagents and adsorbent}

All the reagents correspond to analytical grade. The $\mathrm{Zn}$ (II) solution was prepared in de-ionised water. The bay leaves were procured from the local market, in Jazan, and then subjected to extensive washing with de-ionised water before leaving it overnight in an oven for drying until it attains a constant weight, while maintaining the temperature at $80{ }^{\circ} \mathrm{C}$. The dried adsorbent was crushed and then subjected to filtering through sieve for acquiring particle size of $300 \mu \mathrm{m}$.

\section{Batch method for adsorption studies}

The required amount of an accurately weighed adsorbent was allowed to equilibrate in contact with $\mathrm{Zn}(\mathrm{II})$ solution of appropriate concentration $\left(2 \times 10^{-3}-1 \times 10^{-2} \mathrm{molL}^{-1}\right)$. The mixture was maintained at a constant $\mathrm{pH}$ with the appropriate buffer solution for optimum time with constant shaking. Then the mixture is subjected to filtration to separate out the filtrate, from the adsorbent, for determining the concentration of the filtrate with Flame Atomic Absorption Spectrometry (FAAS).

\section{RESULTS AND DISCUSSIONS}

\section{Characterization}

FT-IR analysis. The investigation of the nature of the interaction between the target metal ion and the adsorbent, a comparative study was done on the FTIR spectra of the loaded and unloaded adsorbent (Figure 1 and Figure 2).

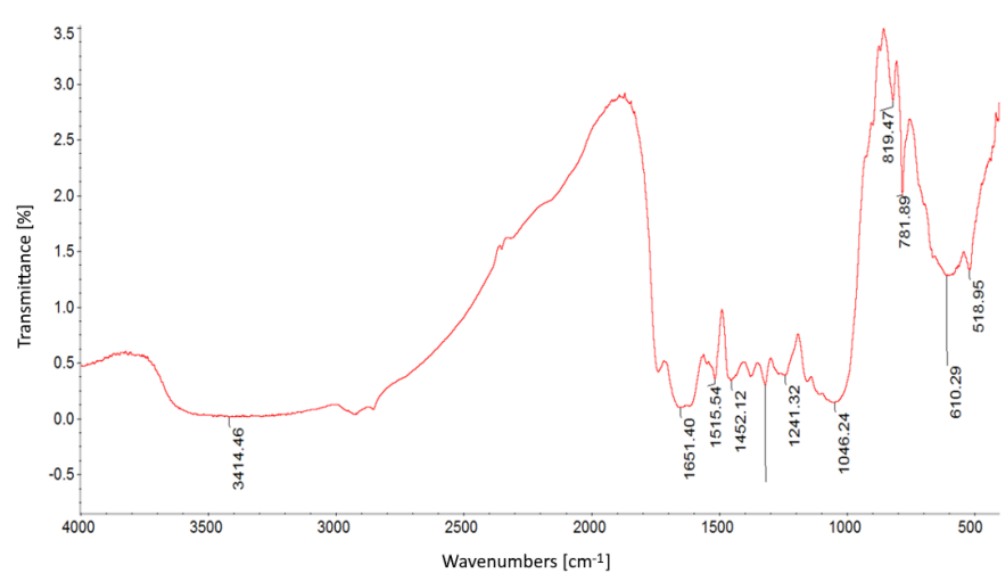

Figure 1. FT-IR spectrum of unloaded bay leaves

The relative decrease in the intensities of the broad band at 3,710-3,902 $\mathrm{cm}^{-1}$, corresponding to $v(\mathrm{NH})$ and $v(\mathrm{OH})$, in the spectrum of the metal laden adsorbent is indicative of their possible involvement in the sorption process. The relative decrease in the broadness of the peaks $\left(3,710-3,902 \mathrm{~cm}^{-1}\right)$ in the case of the metal laden adsorbent may be attributed to the diminishing hydrogen bonding due to the participation of the $-\mathrm{NH}$ and $-\mathrm{OH}$ groups in metal retention [21, 22]. The appearance of the band at $2,917 \mathrm{~cm}^{-1}$, which may correspond to the collective effect of the stretching vibration of 
double bond and the deformation band of $\mathrm{NH}$ (in the metal loaded adsorbent) may be due to its possible role in metal retention [23]. The appearance of bands at 2,304-2,349 $\mathrm{cm}^{-1}$ in the metal loaded adsorbent represents the shift of $v(\mathrm{NH})$ after metal retention. Moreover, the shift in the bands from 1,241 (unloaded adsorbent) to $1,250 \mathrm{~cm}^{-1}$ and 1,046 (unloaded adsorbent) to $1,055 \mathrm{~cm}^{-1}$ may indicate the role of $v(\mathrm{C}-\mathrm{O})$ and the bending vibration of $\mathrm{OH}$ in the retention of metal.

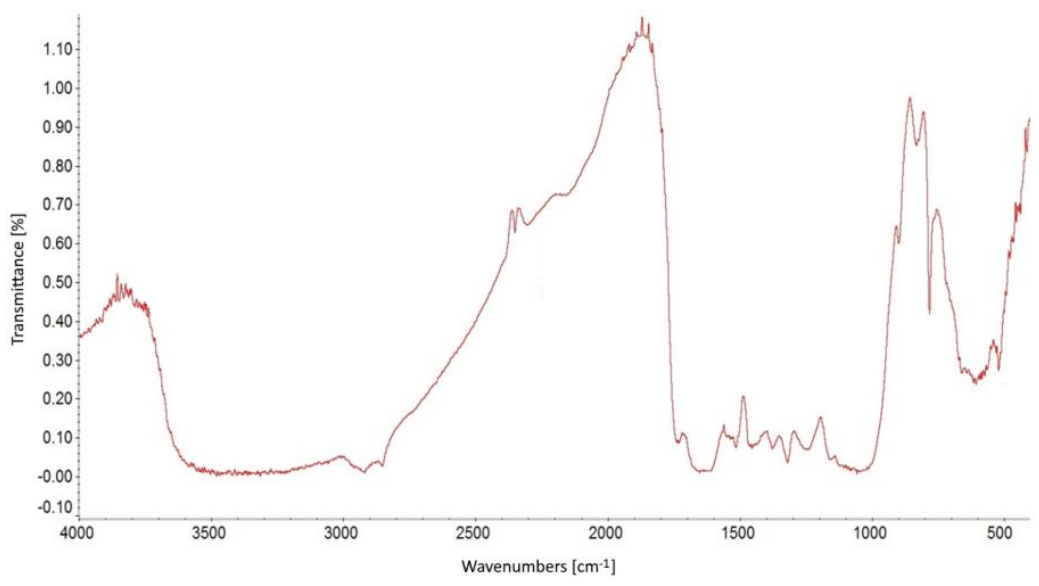

Figure 2. FT-IR spectrum of Zn(II) laden adsorbent

Hydrogen capacity and water regain capacity. The movement of the metal ion phase is facilitated by the presence of interstitial and/or trapped aqueous phase in the biomass. The water regain capacity would indicate the hydrophilicity of the biomass (bay leaves). Water regain capacity may be defined as the amount of water absorbed by $1.0 \mathrm{~g}$ of the biomass [24]. An amount of $2.0 \mathrm{~g}$ of dried ground bay leaves was allowed to soak in doubly distilled water for $48 \mathrm{~h}$, and then filtered by suction. The collected residue of biomass on the filter is then allowed to dry in air and weighed. The air-dried biomass is then dried overnight at $80^{\circ} \mathrm{C}$ and then the constant weight is noted.

The water regain value was calculated as [24]:

$$
W=\left(m_{w}-m_{d}\right) / m_{d}
$$

where $m_{w}$ is the weight of the air-dried polymer after filtration by suction and $m_{d}$ is the weight of the resin after drying at $80{ }^{\circ} \mathrm{C}$ overnight.

The water regain capacity was found to be $6.2 \mathrm{mmolg}^{-1}$. For overall hydrogen ion capacity, an accurately weighed $(1.0 \mathrm{~g})$ of dried ground bay leaves was added to 4.0 M HCl contained in a beaker. After filtering the acid-treated biomass, it was then washed with distilled water until there was no leaching of free acid and subsequently dried at $60^{\circ} \mathrm{C}$ for $3 \mathrm{~h}$. The acidified biomass was then allowed to reach equilibrium (with constant stirring) with a specific volume of $0.1 \mathrm{M} \mathrm{NaOH}$ solution at room temperature. The excess alkali is then titrated against $0.1 \mathrm{M} \mathrm{HCl}$. The overall hydrogen ion capacity was found to be $3.01 \mathrm{mmolg}^{-1}$.

Chemical stability. Several portions of fixed amount of the dried ground biomass was allowed to soak separately in 2 to $4 \mathrm{M}$ of $\mathrm{HCl} / \mathrm{HNO}_{3} / \mathrm{H}_{2} \mathrm{SO}_{4}$ and 2 to $4 \mathrm{M}$ of $\mathrm{NaOH}$ for $30 \mathrm{~min}$ (with constant stirring) and then subjected to loading and elution cycle (after washing and drying). It was found that there was no loss in the sorption capacity upto $3 \mathrm{M}$ of mineral acid and $4 \mathrm{M}$ of $\mathrm{NaOH}$. However, about $10 \%$ loss in sorption capacity was observed with the samples which were soaked in acids of $>3 \mathrm{M}$ and base $(\mathrm{NaOH})$ of 
$>5 \mathrm{M}$. Hence, it may be concluded that there is no degeneration of the biomass in slightly acidic and/or alkaline medium.

\section{Effect of contact time}

From the plot of amount of $\mathrm{Zn}$ (II) retained versus the equilibration time (Figure 3), it may be noted that a constant adsorption capacity of $6.25 \mathrm{mg} \mathrm{g}^{-1}$ was observed after $60 \mathrm{~min}$ of contact time, thereby giving the maximum saturation limit of bay leaves, as an adsorbent.

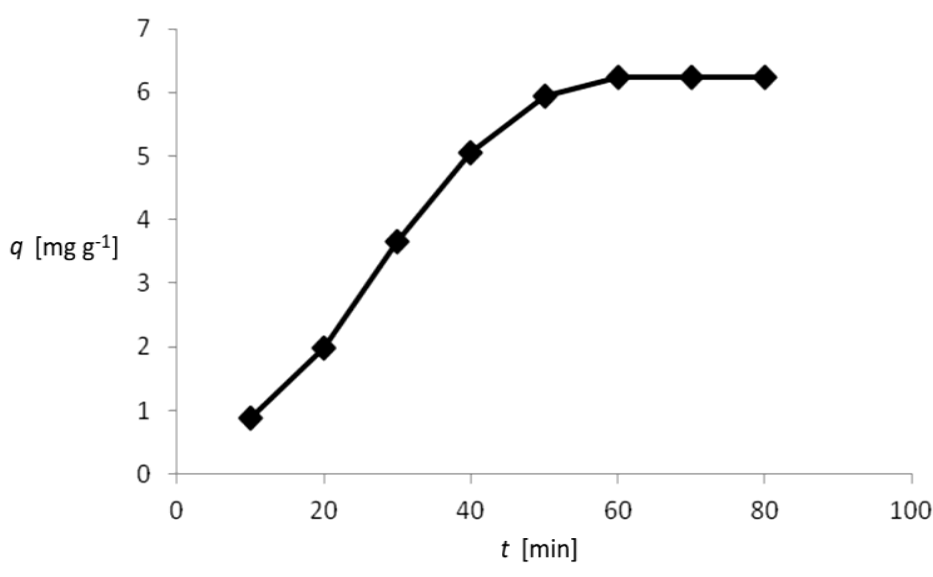

Figure 3. The effect of contact time on adsorption of $\mathrm{Zn}(\mathrm{II})$

\section{Effect of pH on removal of heavy metal}

Since there is always a competition offered by the hydrogen ions, the consideration of $\mathrm{pH}$ of the medium is very important. Hence, the plot of amount of adsorbed $\mathrm{Zn}$ (II) versus $\mathrm{pH}$ (Figure 4) indicates very low retention at $\mathrm{pH} \mathrm{1-3,} \mathrm{thereafter} \mathrm{a} \mathrm{steep} \mathrm{rise} \mathrm{in} \mathrm{the}$ adsorption takes place up to $\mathrm{pH} 5.0$. At $\mathrm{pH}>3$, the positively charged metal ion dominates over the available $\mathrm{H}_{3} \mathrm{O}^{+}$ions and thereby more negatively charged metal binding sites are available for binding with metal. Again a decline in the adsorption of metal was observed after $\mathrm{pH} 5.0$, which may be attributed to the deterioration of metal binding sites [25].

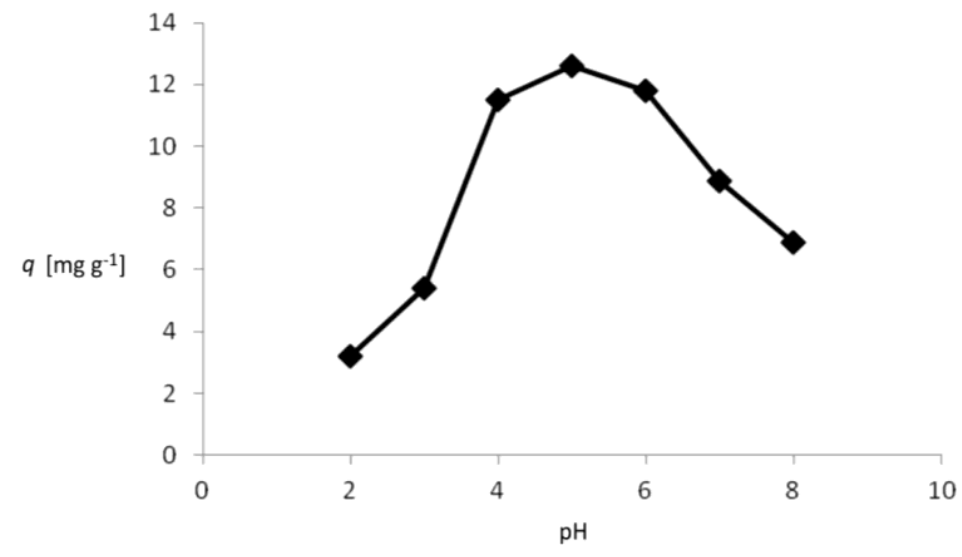

Figure 4. Effect of $\mathrm{pH}$ on the adsorption of $\mathrm{Zn}$ (II)

\section{Effect of temperature on the uptake of metal}

The absorption of $\mathrm{Zn}$ (II) on to bay leaves is favored at higher temperature which indicates the involvement of some chemical interactive forces. With increasing 
temperature, from $20-50{ }^{\circ} \mathrm{C}$, the adsorption capacity was found to increase from $0.33 \mathrm{mmolg}^{-1}$ to $0.50 \mathrm{mmolg}^{-1}$ within $60 \mathrm{~min}$ of contact time. Before reaching the time of equilibration, a kinetically controlled adsorption is reflected by the fact that with the increase in temperature the adsorption increased. The adsorption trend observed after the equilibrium time suggest that more binding sites may be available at higher temperature that leads to higher adsorption.

\section{Effect of initial concentration and adsorbent mass}

In the batch equilibration method, the factor, namely initial concentration of metal ions, has great significance as it facilitates in overcoming the resistance for mass transfer of metal ions between the two phases (namely, aqueous and the solid phase). Therefore, as expected, the adsorption capacity increased with increasing initial metal ion concentration.

When the amount of the adsorbent was increased, the uptake of $\mathrm{Zn}$ (II) from the solution increased from 4.75 to $6.25 \mathrm{mg} \mathrm{g}^{-1}$ (Figure 5), which may be attributed to the fact that more binding sites were available.

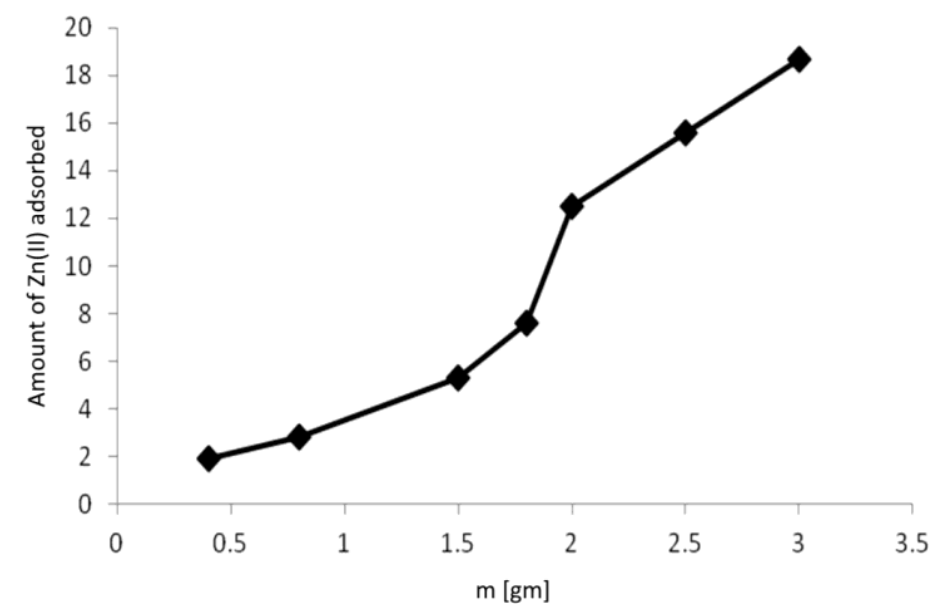

Figure 5. Effect of the adsorbent mass on the adsorption of $\mathrm{Zn}(\mathrm{II})$

\section{Adsorption isotherm studies}

Equilibrium isotherms give an insight into some of the important characteristics of the adsorption system. Therefore, three important isotherm models, namely Langmuir, Freundlich and Dubinin-Radushkevich isotherms [26-28], have been studied at 20-50 ${ }^{\circ} \mathrm{C}$.

The Langmuir isotherm (Figure 6) may be reproduced as follows:

$$
\frac{1}{q_{e}}=\frac{1}{q_{\max }}+\left(\frac{1}{q_{\max } K_{L}}\right) \frac{1}{C_{e}}
$$

where $q_{e}$ is the concentration of $\mathrm{Zn}(\mathrm{II})$ retained on bay leaves $\left(\mathrm{molg}^{-1}\right) ; C_{e}$ is the concentration of $\mathrm{Zn}$ (II) solution ( $\mathrm{molL}^{-1}$ ); $q_{\max }$ is the adsorption capacity (monolayer) of bay leaves $\left(\mathrm{molg}^{-1}\right)$; and $K_{L}$ is the Langmuir adsorption constant $\left(\mathrm{dm}^{-3} \mathrm{~mol}^{-1}\right)$. A separation factor $R_{L}$, a dimensionless constant which indicates the shape of the isotherms to be either unfavourable $\left(R_{L}>1\right)$, linear $\left(R_{L}=1\right)$, favourable $\left(0<R_{L}<1\right)$ or irreversible $\left(R_{L}=0\right)$ may be defined as:

$$
R_{L}=\frac{1}{1+K_{L} C_{o}}
$$




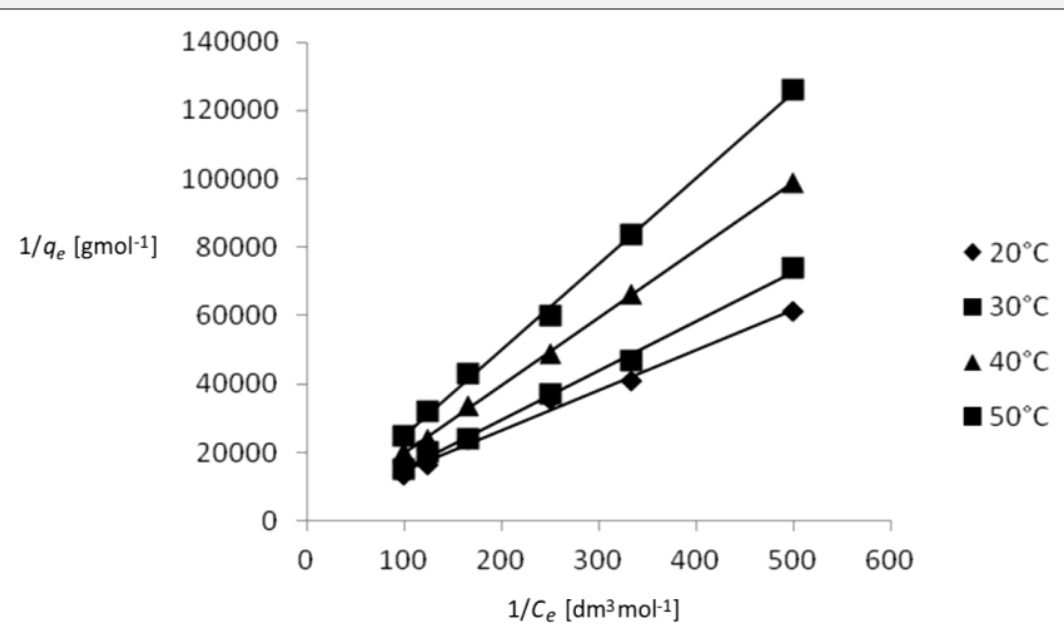

Figure 6. Langmuir plot for the adsorption of $\mathrm{Zn}$ (II)

While Freundlich isotherm (Figure 7) is represented by:

$$
\ln q_{e}=\ln K_{F}+\frac{1}{n} \ln C_{e}
$$

where $K_{F}$ and $n$ are Freunlich adsorption isotherm constants $\left(\mathrm{dm}^{3} \mathrm{~g}^{-1}\right)$ and Dubinin-Radushkevich isotherms (Figure 8) is represented by:

$$
\ln q_{e}=\ln q_{m}-\beta \varepsilon^{2}
$$

where $\beta$ correspond to the mean free energy of adsorption $\left(\mathrm{mol}^{2} \mathrm{~J}^{-2}\right) ; q_{m}$ is the capacity of saturation (theoretical), and $\varepsilon$ is the Polanyi potential, correlated as:

$$
R T \ln \left[1+\left(1 / C_{e}\right)\right]
$$

where $R\left(\mathrm{Jmol}^{-1} \mathrm{~K}^{-1}\right)$ represents the gas constant, while $T(\mathrm{~K})$ indicates absolute temperature. The constant, $\beta$ corresponds to the free energy $E\left(\mathrm{kJmol}^{-1}\right)$ of adsorption and can be correlated as:

$$
E=\frac{1}{(2 \beta)^{1 / 2}}
$$

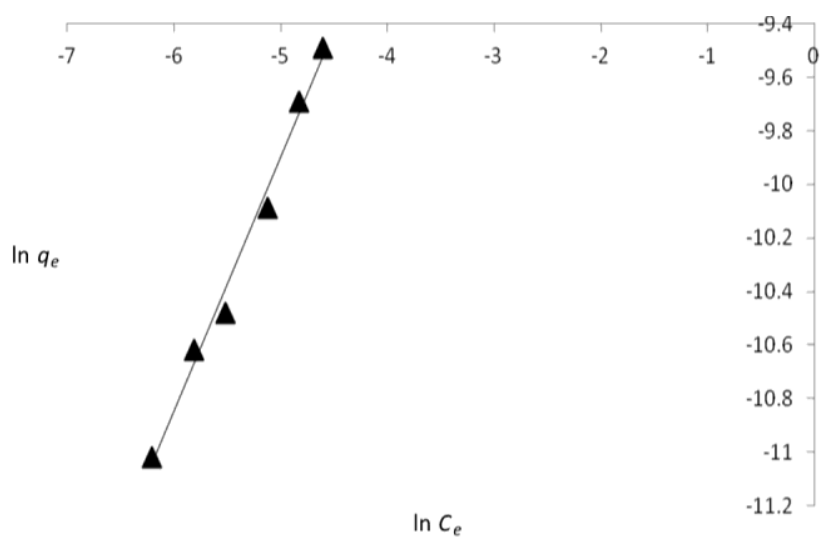

Figure 7. Freundlich plot for the adsorption of $\mathrm{Zn}$ (II) 


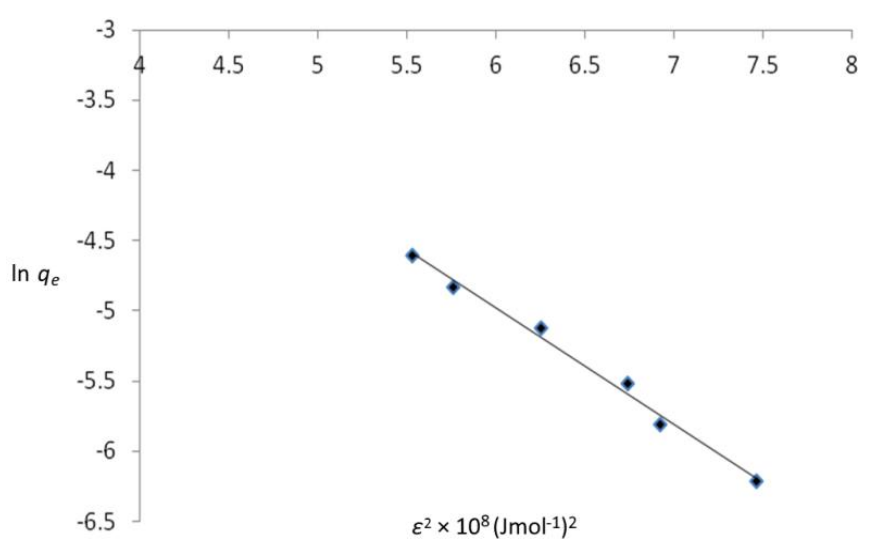

Figure 8. Dubinin-Radushkevich plot for the adsorption of $\mathrm{Zn}(\mathrm{II})$

As illustrated in Table 1 and Table 2, the surface of the adsorbent is composed of both homogeneous as well as heterogeneous adsorption patches since all the isotherm models are befitting.

The $R_{L}$ and $n$ (Table 1 and Table 2, respectively) values also suggest the favorability of the adsorption process. The magnitude of $E$ (Table 2) reflects the nature of adsorption process as of physical nature [29].

Table 1. Values of Langmuir isotherms constants for the adsorption of $\mathrm{Zn}(\mathrm{II})$ at various temperature

\begin{tabular}{ccccc}
\hline$t\left[{ }^{\circ} \mathrm{C}\right]$ & $q_{\max }\left[\mathrm{molg}^{-1}\right]$ & $K_{L}\left[\mathrm{dm}^{3} \mathrm{~mol}^{-1}\right]$ & $r_{L}^{2}$ & $R_{L}$ \\
\hline 20 & $3.35 \times 10^{-4}$ & 25.27 & 0.98 & 0.79 \\
30 & $4.02 \times 10^{-4}$ & 17.99 & 0.98 & 0.85 \\
40 & $4.52 \times 10^{-4}$ & 11.59 & 0.98 & 0.98 \\
50 & $5.00 \times 10^{-4}$ & 8.17 & 0.97 & 0.92 \\
\hline
\end{tabular}

Table 2. Values of Freundlich and Dubinin-Radushkevichisotherm constants

\begin{tabular}{cccc}
\hline \multicolumn{2}{c}{ Freundlich } & \multicolumn{2}{c}{ Dubinin-Radushkevich } \\
\hline$n$ & 0.95 & $\beta\left[\mathrm{mol}^{2} \mathrm{~kJ}^{-2}\right]$ & -0.83 \\
$K_{F}\left[\mathrm{dm}^{3} \mathrm{~g}^{-1}\right]$ & $5.86 \times 10^{-3}$ & $E\left[\mathrm{kJmol}^{-1}\right]$ & 0.77 \\
$r_{F}^{2}$ & 0.98 & $r_{D-R}^{2}$ & 0.99 \\
\hline
\end{tabular}

\section{Kinetics studies}

The appropriate rate expressions, that may represent the adsorption process, may be investigated for supporting the possible reaction mechanisms [30]. Hence, the studied kinetic models including pseudo-first-order equation, given as:

$$
\frac{d q_{t}}{d t}=k_{1}\left(q_{1}-q_{t}\right)
$$

which on integration gives:

$$
\frac{1}{q_{t}}=\frac{1}{q_{1}}+\frac{k_{1}}{q_{1} t}
$$


where $q_{1}$ and $q_{t}$ represent the amount of $\mathrm{Zn}$ (II) retained at equilibrium and at time $t$ $\left(\mathrm{mg} \mathrm{g}^{-1}\right)$, respectively, while $k_{1}$ indicates the pseudo-first-order rate constant $\left(\mathrm{min}^{-1}\right)$ of adsorption, pseudo-second order equation, given as:

$$
\frac{d q_{t}}{d_{t}}=k_{2}\left(q_{2}-q_{t}\right)^{2}
$$

which on integration gives:

$$
\frac{t}{q_{t}}=\frac{1}{k_{2} q_{2}^{2}}+\frac{t}{q_{2}}
$$

where $q_{2}$ represents the maximum adsorption capacity $\left(\mathrm{mg} \mathrm{g}^{-1}\right)$ corresponding to pseudo-second-order retention; $q_{t}$ indicates amount of retained $\mathrm{Zn}(\mathrm{II})$ at equilibrium time $t\left(\mathrm{mg} \mathrm{g}^{-1}\right) ; k_{2}$ is the equilibrium rate constant for pseudo-second-order $\left(\mathrm{gmg}^{-1} \mathrm{~min}^{-1}\right)$ and intraparticle diffusion (Figure 9) represented by:

$$
q_{t}=k_{p} t^{1 / 2}+C
$$

where $C$ represents the intercept and the intraparticle diffusion rate constant $\left(\mathrm{mg} \mathrm{g}^{-1} \min ^{-1 / 2}\right)$ is indicated by $k_{p}$.

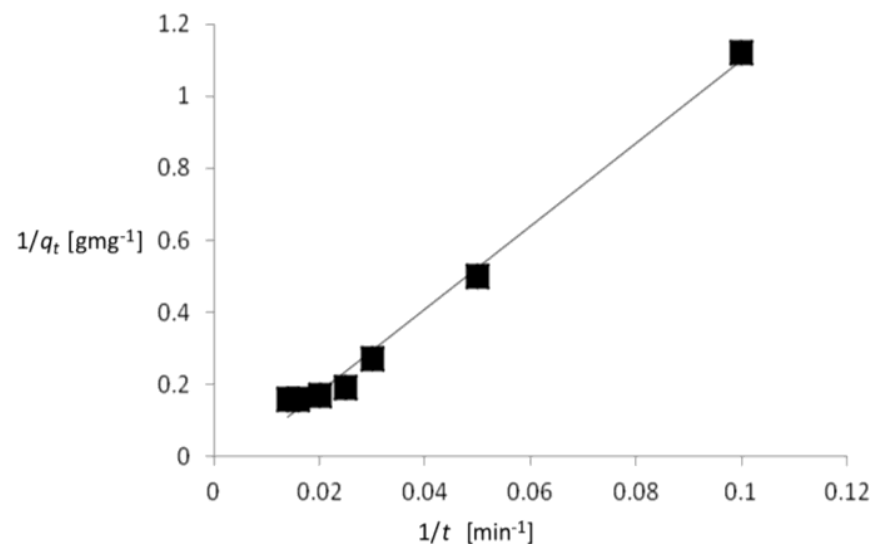

Figure 9. Pseudo-first-order plot for the adsorption of $\mathrm{Zn}$ (II)

From the kinetic parameters obtained (Table 3), it may be inferred that pseudo-first order model (Figure 9) may be one of the routes for the adsorption of $\mathrm{Zn}$ (II) as suggested by the value of the correlation coefficients, which is greater than 0.99 . However, although the correlation coefficients of pseudo-first-order kinetic model is higher than that for the intraparticle diffusion model (Figure 10), it may be inferred that the intraparticle diffusion may partially control the adsorption of $\mathrm{Zn}$ (II), at least up to $60 \mathrm{~min}$ of contact time (Figure 10). Since, the linear portion does not pass through the origin therefore it is not the rate limiting step [31].

Table 3. Kinetic parameters for the adsorption of $\mathrm{Zn}(\mathrm{II})$

\begin{tabular}{ccccccccc}
\hline $\begin{array}{c}k_{1} \\
{\left[\mathrm{~min}^{-1}\right]}\end{array}$ & $\begin{array}{c}q_{1} \\
{\left[\mathrm{mg} \mathrm{g}^{-1}\right]}\end{array}$ & $r_{1}^{2}$ & $\begin{array}{c}k_{2} \\
{\left[\mathrm{gmg}^{-1} \min ^{-1}\right]}\end{array}$ & $\begin{array}{c}q_{2} \\
{\left[\mathrm{mg} \mathrm{g}^{-1}\right]}\end{array}$ & $r_{2}^{2}$ & $\begin{array}{c}k_{p} \\
{\left[\mathrm{mg} \mathrm{g}^{-1} \mathrm{~min}^{-1 / 2}\right]}\end{array}$ & $\begin{array}{c}C \\
{\left[\mathrm{mg} \mathrm{g}^{-1}\right]}\end{array}$ & $r_{p}^{2}$ \\
\hline 217.55 & 18.87 & 0.99 & 14,080 & 40.00 & 0.13 & 1.27 & 3.30 & 0.98 \\
\hline
\end{tabular}




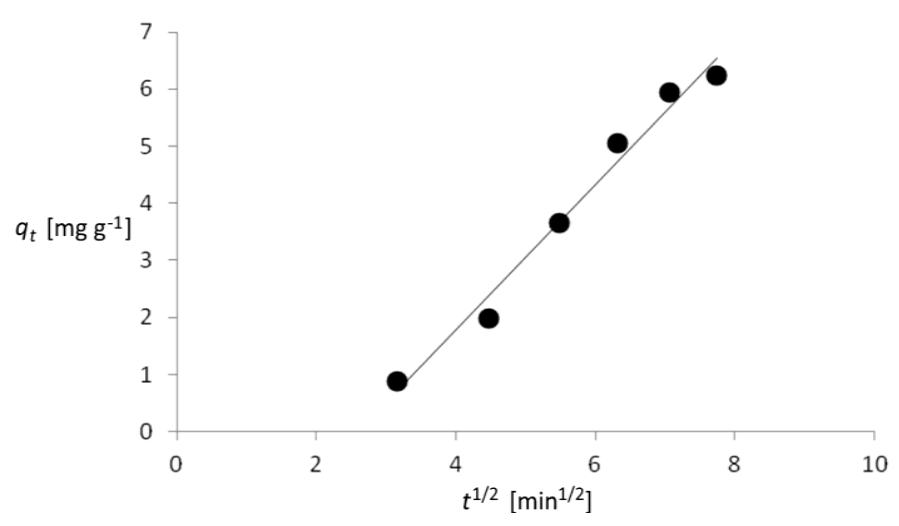

Figure 10. Intraparticle diffusion plot for the adsorption of $\mathrm{Zn}(\mathrm{II})$

\section{Thermodynamic parameters of adsorption}

The correlation between $\Delta G^{0}$ (free energy), $\Delta H^{0}$ (enthalpy), $\Delta S^{0}$ (entropy) and $K_{L}$ (equilibrium constant) is given as:

$$
\begin{gathered}
\Delta G^{0}=-R T \ln K_{L} \\
\ln K_{L}=-\frac{\Delta G^{0}}{R T}=-\frac{\Delta H^{0}}{R T}+\frac{\Delta S^{0}}{R}
\end{gathered}
$$

The value of $\Delta G^{0}<0$ (Gibbs free energy), indicates that the retention of the metal ion on the adsorbent occurs spontaneously (Table 4).

Table 4. Thermodynamic parameters calculated from the Langmuir isotherm constant $\left(\mathrm{K}_{\mathrm{L}}\right)$ for the adsorption of $\mathrm{Zn}(\mathrm{II})$

\begin{tabular}{cccc}
\hline$t\left[{ }^{\circ} \mathrm{C}\right]$ & $\Delta G^{0}\left[\mathrm{kJmol}^{-1}\right]$ & $\Delta H^{0}\left[\mathrm{kJmol}^{-1}\right]$ & $\Delta S^{0}\left[\mathrm{JK}^{-1} \mathrm{~mol}^{-1}\right]$ \\
\hline 20 & -7.26 & & \\
30 & -7.28 & 26.60 & -62.71 \\
40 & -6.37 & & \\
50 & -5.64 & & \\
\hline
\end{tabular}

An endothermic reaction is suggested by the positive value of $\Delta H^{0}$, while the negative value of $\Delta S^{0}$ indicates that there is a decrease in the randomness at the interface between solid and the solution during the adsorption of $\mathrm{Zn}$ (II) onto the adsorbent (Figure 11).

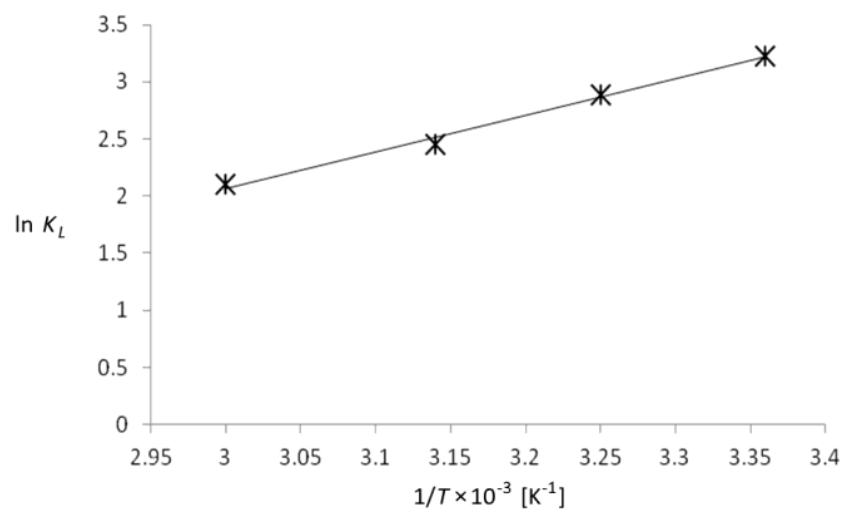

Figure 11. Estimation of thermodynamic parameters for the adsorption of $\mathrm{Zn}(\mathrm{II})$ 


\section{Regeneration studies}

In order to retrieve the unloaded biomass (for reuse), several mineral acids of varying concentration were tried for eluting the sorbed metal ions. However, $0.1 \mathrm{M} \mathrm{HCl}$ was found to give the best result with $100 \%$ recovery of the metal ions. The recovered biomass was then subjected to several cycles of loading and elution and was found to retain $95 \%$ of the sorption capacity up to 3 cycles.

\section{CONCLUSION}

An ecofriendly and low cost bio-sorbent is offered by bay leaves. This simple procedure provides an easy and simple methodology for the remediation of wastewater. The results of the studied Langmuir, Freundlich and Dubinin-Radushkevich isotherms, reflect the physio-chemical mechanism of adsorption that follows pseudo-second order kinetics as well as intra-particle diffusion model. The favourable nature of the adsorption process (that has led to the retention of the metal ions) is also indicated by the thermodynamic studies conducted at the optimized conditions of $\mathrm{pH} 5,25^{\circ} \mathrm{C}$ and $2 \times 10^{-3}-1 \times 10^{-2}$ molL $^{-1}$ of $\mathrm{Zn}$ (II) solutions. The use of waste products, such as, bay leaves, serves the dual purpose of valorization of waste and remediation of wastewater. Hence, this methodology may contribute to the sustainability of a clean environment by avoiding the accumulation of excessive waste, that takes considerable time for degradation, and subsequently diminishing the probability of releasing foul odor and platform for thriving of infectious organisms.

\section{ACKNOWLEDGEMENT}

The authors are grateful to Khadejah Otaif for the help and instrumental facility provided at College of Arts and Science, Samtah (Jazan University).

\section{REFERENCES}

1. Islam, A., Laskar, M. A. and Ahmad, A., Characterization and Application of 1-(2-pyridylazo)-2-naphthol Functionalized Amberlite XAD-4 for Preconcentration of Trace Metal Ions in Real Matrices, J. Chem. Eng. Data, Vol. 55, No. 12, pp 5553-5561, 2010, http://dx.doi.org/10.1021/je100272s

2. Mohammed, A. S., Kapri, A. and Goel, R., Heavy Metal Pollution: Source, Impact, and Remedies (Khan, M. S., Zaidi, A., Goel, R. and Musarrat, J., eds.) Biomanagement of Metal-Contaminated Soils, Springer Netherlands, Vol. 20, pp 1-28, 2011, http://dx.doi.org/10.1007/978-94-007-1914-9_1

3. Islam, A., Laskar, M. A. and Ahmad, A., The Efficiency of Amberlite XAD-4 Resin Loaded with 1-(2-pyridylazo)-2-naphthol in Preconcentration and Separation of some Toxic Metal Ions by Flame Atomic Absorption Spectrometry, Environ. Monit. Assess., Vol. 175, No. 1-4, pp 201-212, 2011, http://dx.doi.org/10.1007/s10661-010-1506-4

4. Akan, J. C., Mohmoud, S., Yikala, B. S. and Ogugbuaja, V. O., Bioaccumulation of Some Heavy Metals in Fish Samples from River Benue in Vinikilang, Adamawa State, Nigeria, Am. J. Anal. Chem., Vol. 3, No. 11, pp 727-736, 2012, http://dx.doi.org/10.4236/ajac.2012.311097

5. Oyaro, N., Juddy, O., Murago, E. N. M. and Gitonga, E., The Contents of Pb, Cu, Zn and Cd in Meat in Nairobi, Kenya, Int. J. Food Agric. Environ., Vol. 5, Issue 3-4, pp 119-121, 2007.

6. Ahmad, A., Siddique, J. A., Laskar, M. A., Kumar, R., Mohd-Setapar, S. H., Khatoon, A. and Shiekh, R. A., New Generation Amberlite XAD Resin for the 
Removal of Metal Ions: A Review, J. Environ. Sci. (China), Vol. 31, pp 104-123, 2015, http://dx.doi.org/10.1016/j.jes.2014.12.008

7. Hammer Sr., M. J. and Hammer Jr., M. J., Water and Wastewater Technology, Prentice Hall, $7^{\text {th }}$ edition, 2011.

8. Gasparikova, E., Kapusta, S., Bodik, I., Derco, J. and Kratochvil, K., Evaluation of Anaerobic-Aerobic Wastewater Treatment Plant Operations, Pol. J. Environ. Stud., Vol. 14, No. 1, pp 29-34, 2005.

9. Kumar, U., Agricultural Products and By-products as a Low Cost Adsorbent for Heavy Metal Removal from Water and Wastewater: A Review, Sci. Res. Essays, Vol. 1, No. 2, pp 33-37, 2006.

10. Rocha, C. G., Zaia, D. A. M., Alfaya, R. V. and Alfaya, A. A., Use of Rice Straw as Biosorbent for Removal of $\mathrm{Cu}(\mathrm{II}), \mathrm{Zn}(\mathrm{II}), \mathrm{Cd}(\mathrm{II})$ and $\mathrm{Hg}(\mathrm{II})$ Ions in Industrial Effluents, J. Hazard. Mater., Vol. 166, No. 1, pp 383-388, 2009, http://dx.doi.org/10.1016/j.jhazmat.2008.11.074

11. Nasernejad, B., Zadeh, T. E., Pour, B. B., Bygi, M. E. and Zamani, A., Comparison of Biosorption Modeling of Heavy Metals (Cr(VI), Cu(II) and Zn(II)) Adsorption from Wastewater by Carrot Residues, Process Biochem., Vol. 40, No. 3, pp 1319-1322, 2005, http://dx.doi.org/10.1016/j.procbio.2004.06.010

12. Vazquez, G., Calvo, M., Freire, M. S., Gonzalez-Alvarez, J. and Antorrena, G., Chestnut Shell as Heavy Metal Adsorbent: Optimization Study of Lead, Copper and Zinc Cations Removal, J. Hazard. Mater., Vol. 172, Issue 2-3, pp 1402-1414, 2009 , http://dx.doi.org/10.1016/j.jhazmat.2009.08.006

13. Oliveira, W. E., Franca, A. S., Oliveira, L. S. and Rocha, S. D., Untreated Coffee Husks as Biosorbents for the Removal of Heavy Metals from Aqueous Solutions, $J$. Hazard. Mater, Vol. 152, Issue 3, pp 1073-1081, 2008, http://dx.doi.org/10.1016/j.jhazmat.2007.07.085

14. Annadurai, G., Juang, H. S. and Lee, D. J., Adsorption of Heavy Metals from Water using Banana and Orange Peels, Water. Sci. Technol., Vol. 47, No. 1, pp 185-190, 2002.

15. Raize, O., Argaman, Y. and Yannai, S., Mechanisms of Biosorption of Different Heavy Metals by Brown Marine Macroalgae, Biotechnol. Bioeng., Vol. 87, No. 4, pp 451-458, 2004, http://dx.doi.org/10.1002/bit.20136

16. Rema, J., Leela, N. K., Krishnamoorthy, B. and Mathew, P. A., Chemical Composition of Cinnamomum Tamala Essential Oil-A Review, Int. J. Med. Arom. Plants, Vol. 27, pp 515-519, 2005.

17. Lohani, H., Singh, S. K., Bhandari, U., Haider, S. Z., Gwari, G. and Chauhan, N., Chemical Polymorphism in Cinnamomum tamala (Buch.-Ham.) Nees. \& Eberm. Growing in Uttarakhand Himalaya (India), J. Che. Pha. Res., Vol. 7, No. 8, pp 67-71, 2015.

18. Sankaran, V., Chakraborty, A., Jeyaprakash, K., Ramar, M. and Chellappan, D. R., Chemical Analysis of Leaf Essential Oil of Cinnamomum tamala from Arunachal Pradesh, India, J. Chem. Pharm. Sci., (Online), Vol. 8, pp 246-248, 2015.

19. Barceloux, D. G., Medical Toxicology of Natural Substances: Foods, Fungi, Medicinal Herbs, Toxic Plants, and Venomous Animals, John Wiley \& Sons, Hoboken, NJ, pp 39-43, 2008, http://dx.doi.org/10.1002/9780470330319.ch4

20. Handa, S. S., Khanuja, S. P. S., Longo, G. and Rakesh, D. D., Extraction Technologies for Medicinal and Aromatic Plants, United Nations Industrial Development Organization and the International Centre for Science and High Technology, ICS-UNIDO, AREA Science Park Padriciano 99, 34012 Trieste, Italy, 2008. 
21. Islam, A., Ahmad, A. and Laskar, M. A., Characterization of a Chelating Resin Functionalized via Azo Spacer and its Analytical Applicability for the Determination of Trace Metal Ions in Real Matrices, J. Appl. Polym. Sci., Vol. 123, Issue 6, pp 3448-3458, 2012, http://dx.doi.org/10.1002/app.34844

22. Islam, A., Ahmad, A. and Laskar, M. A., Flame Atomic Absorption Spectrometric Determination of Trace Metal Ions in Environmental and Biological Samples after Preconcentration on a Newly Developed Amberlite XAD-16 Chelating Resin Containing p-Aminobenzene Sulfonic Acid, J.AOACInt., Vol. 98, No. 1, pp 165-175, 2015, http://dx.doi.org/10.5740/jaoacint.11-429

23. Kuyucak, N. and Volesky, B., The Mechanism of Cobalt Biosorption, Biotechnol. Bioeng., Vol. 33, No. 7, pp 823-831, 1989, http://dx.doi.org/10.1002/bit.260330705

24. Islam, A., Laskar, M. A. and Ahmad, A., Preconcentration of Metal Ions Through Chelation on a Synthesized Resin Containing O, O Donor Atoms for Quantitative Analysis of Environmental and Biological Samples, Environ. Monit. Assess., Vol. 185, Issue 3, pp 2691-2704, 2013, http://dx.doi.org/10.1007/s10661-012-2740-8

25. Puranik, R. and Paknikar, K. M., Biosorption of Lead and Zinc from Solutions using Streptoverticillium Cinnamoneum Waste Biomass, J. Biotechnol., Vol. 55, No. 2, pp 113-124, 1997, http://dx.doi.org/10.1016/S0168-1656(97)00067-9

26. Langmuir, I., The Adsorption of Gases on Plane Surfaces of Glass, Mica and Platinum, J. Am. Chem. Soc., Vol. 40, No. 9, pp 1361-1403, 1918, http://dx.doi.org/10.1021/ja02242a004

27. Freundlich, H. M. F., Over the Adsorption in Solution, J. Phys. Chem., Vol. 57, pp 385-470, 1906.

28. Dubinin, M. M. and Radushkevich, L. V., Equation of the Characteristic Curve of Activated Charcoal, Proc. Acad. Sci. U.S.S.R. Phys. Chem. Sect., Vol. 55, pp 331, 1947.

29. Helfferch, F., Ion exchange, Mc Graw Hill Book Co. Inc., New York, 1962.

30. Ahmad, R., Kumar, R. and Laskar, M. A., Adsorptive Removal of $\mathrm{Pb}^{2+}$ from Aqueous Solution by Macrocyclic Calix[4]naphthalene: Kinetic, Thermodynamic, and Isotherm Analysis, Environ. Sci. and Poll. Res., Vol. 20, No. 1, pp 219-226, 2013, http://dx.doi.org/10.1007/s11356-012-0838-8

31. Crank, J., The Mathematics of Diffusion, Clarendon Press, London, 1965. 